Çeşm-i Cihan:

Tarih Kültür ve Sanat Araştırmaları E - Dergisi ISSN: 2149-5866 Cilt:5, Sayı:2, s. 48-60, Kıș 2018

Araştırma-İnceleme

DOİ:_10.30804/cesmicihan. 488675 BARTIN - TÜRKIYE
Bartın Üniversitesi

Bartın ve Yöresi

Tarih - Kültür Araştırmaları

Uygulama ve Araştırma

Merkezi

(BAYTAM)

\title{
THE KING IS PREGNANT: THE LEFT HAND OF DARKNESS AND GENDER AS A POWER ISSUE
}

\section{Dr. Öğr. Üyesi Murat GÖÇ*}

\begin{abstract}
Ursula Le Guin's masterpiece The Left Hand of Darkness is based on the story of an Investigator, $\mathrm{Ai}$, who has been sent to the planet of winter, Gethen, to convey the message of an interplanetary Council. Gethen is dominated by royal families and little kingdoms, Karhide and Ortogeyn. The book consists of short legends told by anonymous characters and accounts of Ai's journey in Karhide, then to Orgoteyn and then back to Karhide. Gethenians were sexually inactive except for a certain period that they called kemer, and they remained androgynous rest of the year. Their outstanding sexual character inevitably has social, political and cultural consequences. Ursula Le Guin experiments with the sexual and gendered qualities of human societies to understand to what extent they influence our cultural and political behaviors. This paper, therefore, will investigate the effects of gender and sexuality on the cultural and political construction of society with particular references to feminist theory and traditions of fantastic fiction written by women.
\end{abstract}

Keywords: Gender, power, fantastic fiction, Ursula Le Guin, The Left Hand of Darkness, American fiction

\section{KRAL HAMİLE: KARANLIĞIN SOL ELİ VE BİR İKTİDAR SORUNU OLARAK TOPLUMSAL CINSIYYT}

Öz: Ursula Le Guin'in bașyapıtı Karanlığın Sol Eli, kış gezegeni Gethen'e yolu düșen ve gezegenlerarası konseyin mesajını ulaştırmakla görevlendirilmiş bir elçinin, Ai'nin, hikayesini anlatır. Gethen asil aileler ve Karhide ve Ortogeyn isimli iki küçük krallık tarafından kontrol edilmektedir. Kitap, her bir bölümde farklı bir anlatıcı tarafından anlatılan kısa öykülerden oluşmuştır. Gethen sakinlerinin en çarpıcı özelliği, Kemer adını verdikleri bir çiftleşme dönemi dışında cinsiyetsiz varlıklar olmalarıdır. Bu çarpıcı biyolojik özelliklerinin elbette toplumsal, kültürel ve politik sonuçları da olacaktır. Ursula Le Guin, bu romanında insan toplumlarının cinsiyet ve cinsiyetlendirilmiş kimliklerinin, ne ölçüde kültürel ve politik davranışlarını etkileyeceğini anlamak üzere bir deney yürütmektedir. Bu makale, bu doğrultuda, cinsellik ve toplumsal cinsiyet kavramlarının toplumun kültürel ve politik yapısı üzerindeki etkilerini, feminist kuram ve kadın yazarların oluşturduğu fantastik edebiyat geleneği ışığında tartışmayı amaçlamaktadır.

Anahtar Kelimeler: Toplumsal cinsiyet, fantastik kurgu, iktidar, Ursula Le Guin, Karanlığın Sol Eli, Amerikan romanı.

\section{The King is Pregnant: The Left Hand of Darkness and Gender as a Power Issue}

What is the first question that we ask about a newborn baby? Ursula Le Guin, The Left Hand Of Darkness.

Feminist movement has undergone noteworthy changes during its history. From the women's suffrage movements to the efforts of creating a feminine language and history and to its leading role in paving the way for masculinity and gay-lesbian studies, women have had to

\footnotetext{
${ }^{*}$ Manisa Celal Bayar Ünv. İngiliz Dili ve Edebiyatı Bölümü
} 
revise and reshape their own definitions of what/who a woman is and should be. What remained unchanged in feminist studies is its emphasis on womanhood and femininity and its rejection and subversion of patriarchal authority. Patriarchy stands at the intersection of social deprivations as a form of physiological, cultural and psychological oppression in houses, workplaces, churches, universities, courthouses and parliaments specific to women, overrun by men (Robbins, 1999, 54). Later on, with the inclusion of deconstruction as a discursive analysis method, especially Lacanian psychoanalysis, linguistics, and Foucauldian notion of power, feminist scholars proposed that sexuality as well as gender is a performance and a construction structured by numerous agents including race, class, culture and power. Then, the primary focus of the feminist critique is to "understand how the category of "women," the subject of feminism, is produced and restrained by the very structures of power through which emancipation is sought" (Butler, 1990, 5) Judith Butler further argues that

We act as if that being of a man or that being of a woman is actually an internal reality or something that is simply true about us, a fact about us, but actually it's a phenomenon that is being produced all the time and reproduced all the time, so to say gender is performative is to say that nobody really is a gender from the start. (Butler, $1988,521)$

Feminist theory extended the limits of structural inequalities manufactured by patriarchal hegemony and defined patriarchy and masculinity as a form of power that exploits people from different cultures, religions, ages, racial and sexual orientations alike. Therefore, a black woman as well as an upper class white woman can be a victim of gendered oppression and discrimination bred by the patriarchal network of power.

Hence, the primary aim of a feminist text will be to decipher and subvert the operations of power and gender tailored by a long standing tradition of patriarchy and authority. Helene Cixous in her The Laugh of the Medusa remarks that

woman must write her self: must write about women and bring women to writing, from which they have been driven away as violently as from their bodies - for the same reasons, by the same law, with the same fatal goal. Woman must put herself into the text - as into the world and into history - by her own movement (Cixous, 1976, 875).

Likewise, feminist critics assumed that there exists an interdependent relation between the language and social and cultural codes and between the texts and external reality. Feminist texts 
either reflect social and historical conditions or attempt to undermine them, and thus are inevitably historical, subjective and political. Feminist criticism often underlines that these texts are inherently produced out of a specific social reality, that they are highly subjective since all literary texts are somehow constructions of a subjective reflection of reality, and that they convey a strong will to change and divert the external reality, which highlights the revolutionary character of feminist texts (Walker, 1990, 154). Elaine Showalter further argues that women need to develop a unique method of reading, writing, and interpreting texts that are peculiar to women only which will eventually liberate them from the boundaries of male discourse and the language of patriarchy. Showalter notes that:

In contrast to [an] angry or loving fixation on male literature, the program of gynocritics is to construct a female framework for the analysis of women's literature, to develop new models based on the study of female experience, rather than to adapt male models and theories. Gynocritics begins at the point when we free ourselves from the linear absolutes of male literary history, stop trying to fit women between the lines of the male tradition, and focus instead on the newly visible world of female culture (Showalter, 1992, 383).

In this sense, fantasy written by women basically problematized and rejected culturally defined formulations of gender roles and sexuality so pervasively that feminist fantastic fiction, in any sense, acts as a political tool, a fundamental attempt to deny the authority of the patriarchal system (Armitt, 2000,3). Ironically enough, the political potential of fantasy was often undermined by Marxist critics suggesting that fantastic fiction was a mystified escapism and alienation caused by a change in the modes of production and corresponding forms of mechanical art. Interpretation and reception of fantastic fiction were therefore confined within a "Lukácsian critique of "decadent" non-real forms" and cultural elitism of Frankfurt School (Miéville, 2004, 336). Critical approaches to fantasy, accordingly, were founded on a sexist assumption that while science-fiction "is characterised by 'cognitive estrangement' and it operates according to a rationalist/scientific mindset". Therefore, science fiction is highly masculine and it has a political potential since the domain of rationality, science, and politics is solely reserved for men and, fantasy can only be classified as "a subliterature of mystification", and its juxtaposition with sci-fi is "rampantly socio-pathological" since the feminine is traditionally associated with the mystique, the unreasonable, and the supernatural (Suvin, 1979, 9). Even more tragically, fantasy is dangerous as it provides the masses with a temporary relief for their insecure, fearful and doubtful pains of social reality (Oskay, 1982, 25). In fact, women 
are archetypal storytellers and bearers of oral tradition ranging from stories, folk tales, fairy tales, mysterious thrillers to legends whereas written literature, with its norms, rules, canonical hierarchies and totality, is perfectly masculine. Women have deliberately created alternative realities and universes to redefine and reconstitute the patriarchal domination of the Symbolic Order by envisioning an alternative reality that either corrects or intensifies the ills of the present (Walker, 1990, 145).

Most works of science fiction and fantasy mainly serve to achieve two main purposes: to enable the reader to make his/her own interpretations (because most science fiction and fantasy texts are readerly texts), and to prove that social reality is not fixed and unquestionable. As women (and in a more general perspective, all different representations of the non-male) are entrapped in a symbolic order embodied by linguistic and discursive forms where social reality and narrator who reflects that given reality are positioned as male and masculine, the form and content of their texts must reveal the "fragmented" and "incomplete" as opposed to what is "complete" and "whole". Brian Attebery suggests that "fantastic literature is full of 'loaded' images, concrete emblems of problematic or valuable psychological and social phenomena. The combination of such images into a narrative order is an attempt to achieve iconic representation, so that the narrative can, like the city map, give us new insight into the phenomena it makes reference to" (Attebery, 2004, 299). In the phallocentric patriarchal discourse, woman is always what is not man, excluded from the culture and the symbolic order. To regain her position in the symbolic order, classical feminism once contributed to the established binary oppositions of man and woman by making womanhood another monolithic body. On the other hand, Judith Butler suggested that woman is a fragmented subject through which complicated and evasive network of power operates:

Significantly, if gender is instituted through acts which are internally discontinuous, then the appearance of substance is precisely that, a constructed identity, a performative accomplishment which the mundane social audience, including the actors themselves, come to believe and to perform in the mode of belief. If the ground of gender identity is the stylized repetition of acts through time, and not a seemingly seamless identity, then the possibilities of gender transformation are to be found in the arbitrary relation between such acts, in the possibility of a different sort of repeating, in the breaking or subversive repetition of that style. (Butler, 1988, 520) 
Therefore, feminist fantasy has been constructed within a decentered narrative formation where the narrator and the narration are given no fixed identity and form, and the narrative structure has been structured like a patchwork (Waugh, 1988, 14).

Among other women fantasy and science fiction writers such as Margaret Atwood, Marge Piercy, Joanna Russ and Fay Weldon, Ursula K. Le Guin has always occupied a distinct position since unlike other women writers. She not only questioned and challenged male authority and domination but also criticized any form of power and control. Her magnum opus, The Left Hand Of Darkness, is therefore widely welcomed due to its awesome suggestion of a bisexual and genderless society. Unsurprisingly, feminist utopias and dystopias have offered various examples of lesbian communities, stories of bisexual, homosexual or even sexless races and gender warfare. On the contrary, Le Guin's novel is quite distinct in her critical stance towards femininity as well as masculinity, which handles the issue as a matter of power and domination rather than a matter of gendered inequalities and oppression.

The Left Hand of Darkness is based on the story of an Investigator, $\mathrm{Ai}$, who has been sent to an unknown land, Gethen, to convey the message of an interplanetary Council. That new planet is dominated by royal families and little kingdoms two of which, Karhide and Ortogeyn, have developed relatively strong and sophisticated governmental structures. The book consists of short legends told by anonymous characters and accounts of Ai's journey in Karhide, then to Orgoteyn and then back to Karhide. Le Guin deliberately refrains from creating a unified and complete narrative form and patches the stories together, sometimes told twice by different characters and sometimes left unfinished and incomplete, which is a typical of feminist science fiction and fantasy texts. For one thing, the central motivation of the author while writing science fiction and fantasy, mostly is not artistic but political and ideological, that is, science fiction and fantasy writers, and especially women, primarily strive to express their resentment towards the external reality rather than creating new artistic forms of narration (Robbins, 1999, $52)$.

Moreover, Le Guin's choice of a fragmented and discontinued narration may account for the decisive subversion of the God-like position of the narrator, which suggests certain forms of authority and hierarchy within the narrative structure, which, in turn, suggests a patriarchal centralization of discourse. In western culture, women are often destined to be the Other of the man and juxtaposed with other non-male forms of gender like infants and homosexuals. Infantilization of women in a male dominated society has become a cultural depiction of patriarchy that women are regarded as immature and imperfect so as to develop and create cultural artifacts. As opposed to "serious" and elaborate forms of art created and consumed by only men, women have created and built up their own art forms such as story telling and 
oratory, weaving and quilt making. Such feminine forms of art are characterized by particularly subjective formulations and locality as well as nonuniformity and imperfectness. Furthermore, fragmented narrative structure may as well be perceived as a rebellion against grammatical and narrative norms of language, which pre-established by a symbolic order which defines itself on the basis of a phallus that condemns women as inferior beings lacking authority and control over the symbolic order. In Western canon, the subject "I" not only refers to first person singular narrator but also stands for an omnipresent male authority and governance over other living things, e.g. animals, vegetation, colored people and women as well (Waugh, 1988, 112). Therefore, deconstructing and decentring the traditional narrative form inevitably brings out the abolishment of patriarchal forms of narration. In The Left Hand Of Darkness, narrator and temporal unity were intentionally left fragmented so that the reader may question the totality and unity of social organization of time and history.

Moreover, Gethenians and their social organization is distinctive for their "extraordinary" physiological traits when compared to Ai's and other Ekumenic peoples' physical bodies. Deformation, transformation, or redefinition of body is a frequent theme in feminist fantastic fiction. Elizabeth Grosz notes that "the body must be regarded as a site of social, political, cultural and geographical inscriptions, production or constitution. The body is not opposed to culture, a resistant throwback to a natural past; it is itself a cultural, the cultural product" (Grosz, 1994, 23). Judith Butler similarly adds that

The body is not a self-identical or merely factic materiality; it is a materiality that bears meaning, if nothing else, and the manner of this bearing is fundamentally dramatic. By dramatic I mean only that the body is not merely a matter but a continual and incessant materializing of possibilities. One is not simply a body, but, in some very key sense, one does one's body and, indeed, one does one's body differently from one's contemporaries and from one's embodied predecessors and successors as well. (Butler, 1998, 521).

One chapter in the novel is particularly noteworthy. The narrator in this chapter is an ambassador in disguise who visits the planet for the first time a while ago to be able to observe the Gethenian people and their culture. As a heterosexual woman, the ambassador is most astonished, and to a certain degree most puzzled, with the awesome sexual physiology of the Gethenian people. Having recovered from the first shock to learn that Gethenians do not have any fixed and continuous sexuality., she reacts fearfully and even pitifully trying to rationalize and explicate the "extraordinariness" of Gethenians: 
In the first phase of kemmer, [the individual] remains completely androgynous. Gender, and potency are not attained in isolation... Yet, the sexual impulse is tremendously strong in this phase, controlling the entire personality... When the individual finds a partner in kemmer, hormonal secretion is further stimulated (most importantly by touch-secretion?scent?) until in one partner either a male or female hormonal dominance is established. The genitals engorge or shrink accordingly, foreplay intensifies, and the partner, triggered by the change takes on the other sexual role in kemmer; they do not know whether they will be the male or the female, and have no choice in the matter.... The culminant phase of kemmer lasts from two to five days, during which sexual drive and capacity are at maximum. It ends fairly abruptly, and if conception has not taken place, the individual returns to the latent phase and the cycle begins anew. If the individual was in the female role and was impregnated, hormonal activity of course continues, and for the gestation and lactation periods this individual remains female... With the cessation of lactation the female becomes once more a perfect androgyne. No physiological habit is established, and the mother of several children may be the father of several more (Le Guin, 1976, 83-89)

That Gethenians were sexually inactive except for estrus periods and they remained androgynous rest of the year, naturally, yield some social and cultural consequences. For instance, in Gethen, as there are no men or women, formation and hierarchy of social institutions change accordingly. There are no marriages in Gethen, nor families but instead they have strong "blood ties" following a matriarchal line and kemmer oath, which, in a way, is equal to earthly marriages. On the other hand, these social and cultural ties and commitments are natural and temporary unlike legally coercive marriages and family kinships on earth. In Gethen, there are maids and servants but the labor division is not based on gender, neither is the division of wealth and titles. Gethenian communes (except Orgoteyn) operate on the base of a communal economy with little or no centralized authority, which results in tribal organizations which are deprived of administrative institutions like schools, government offices, temples and armed forces like police or military power. Le Guin intentionally makes references to premodern types of social organizations in her alternative world suggesting that Gethen is a feminine world unlike the masculine order and patriarchy with its well established a priori institutions on earth. Besides, tribal matriarchal communities in Gethen are partly a consequence of natural conditions such as climate and geographical conditions of the planet. 
Unceasingly, Gethenians have to struggle with the restrictions and limitations imposed by the nature, just like a woman whose body is a prison to herself most of the time. Just like a woman, Gethenian people deny and reconcile with their physical world, shape and are shaped, beat and are beaten, restrict and are restricted.

In addition, as sexual activity is a hormonal necessity and a biological need, and occurs only when two people are simultaneously excited, there is no sexual harassment, no rape and no sexual assault in Gethen. What is more, Gethenians are unaware of dating rituals on earth that reinforce some certain gendered codes of behavior and reproduce gendered stereotypes. Procreation and sexual intercourse are deprived of all those "moral" and sublime connotations mainly determined by phallocentric point of view. Sexuality and sexual activity are an indispensable part of their life that takes away all the guilt, shame and taboos attached to sexuality. Michel Foucault asserts that on e of the primary attainments of modernity and modern state was the restriction and redefinition of sexuality by making it unnatural and therefore invisible in the public arena while dispersing it in the discourse of everyday life (Foucault, 1978, 40-41). Thus, while, officially, sexuality has been besieged by the army of taboos, embarrassments and alienations, it has also been an inseparable part of the official regulations in schools, government offices, military organizations and houses. Therefore, Gethenian society indicates a pre-modern sensitivity and perception towards sexuality and sexual activity unlike the notion of suppressed sexuality on earth, which defines and redefines, groups and subgroups, and condemns and sublimes sexual identities and sexual activities.

Obviously, Le Guin tries to subvert patriarchal values by creating such an imaginary planet where the kings get pregnant and men are deprived of their male dignity and supremacy and where women don't have to be protected and imprisoned within social and historical myths which, ostensibly, infantilize and demean them. In most feminist utopias and dystopias alike, institutions of patriarchal autocracy, marriage, army, governments and religion, are confronted, mocked and knocked down (Robbins, 1999, 64). A heterosexual character, someone who bears the traces of conventional societies that could enable us to make a comparison is generally placed at the heart of "queerness" and forces us to reconsider limits of the normalities and abnormalities in the external reality we live in.

It is often argued that the basic motivation of one's attitudes is determined by his/her gender that women tend to handle the issues in a more interrelated and more complex way in a wider perspective while men think more directly and plainly obsessed with only causes and results. The Left Hand of Darkness moves beyond these utterly simplistic generalizations to unveil the complexity of attitudes of androgynous people. The novel, therefore, is not only about gender issues, also about treachery, feud, friendship and solidarity. Ai is left perplexed in the 
middle of soft lies, suggestions, implications and misinformation. Each different party and group tries to exploit Ai's position and mission to use him to achieve their hideous plans. Everybody in Gethen, more or less, is a part of a plot that is hard to reveal and unravel for a heterosexual man whose mind is destined to judge the present causes and results of the events, which often misleads him and causes him to think over and over again what they have already said or done and what their underlying motives are. Such a plain thinking doesn't allow Ai to understand the power struggles in Karhide, nor in Orgoteyn, which, in the end, send him to exile and prison. Gethenian people's attitudes are mainly shaped around an abstract notion, shifgretor, a kind of aggression, a conflict without physical violence and an exaggerated form of self-esteem and pride. It can be stated that shifgretor directs their mode of thinking, which causes them to hamper to express their real thoughts and emotions and turns out to be a way of self-censure, which seems to me a highly feminine. Just like Gethenians, to refrain from physical aggression and power struggle that may lead to violence, women have had to develop a way of doublespeak that employs a carefully constructed language. It always hides what's behind and second thoughts that can't be easily translated into men's direct and plain language where conflicts and problems are solved with physical power and primitive forms of power struggle. At this point, it seems inevitable to differentiate feminine shifgretor and masculine pride and honor that while the former is the fundamental form of limited, personal and temporary interpersonal aggression that can exist within anybody, the latter eventually leads to nationalism and militarism, which, actually, is what happens in Karhide in the end.

Not only people but also nations and societies can reflect gendered traits as a whole. In this sense, it can be argued that Le Guin purposely designed two different societies, Karhide and Orgoteyn, to symbolize two main genders. Karhide, with its decentred governmental organizations, with its economical structure based on autonomy and communality and its lacking of armed forces, represents the feminine part of the Gethenian society. There are no strict laws and obligations in Karhide, nor a written legislation or an organized police force to enforce the laws. They have deliberately chosen to progress mutually and therefore they emphasized mutual benefits and the importance of existence here and now. Le Guin states her purpose in creating such a feminine form of society in her article:

The "female principle" has historically been anarchic; that is, anarchy has historically been identified as female. The domain allotted to women, - "the family", for example- is the area of order without coercion, rule by custom by force. Men have reserved the structures of social power to themselves (and those few women whom they admit to it on male terms, such as queens, prime 
ministers); men make the wars and peaces, men make, enforce, and break the laws. On Gethen, the two polarites we perceive through our cultural conditioning as male and female are neither, and are in balance: consensus with authority, decentralizing with centralizing, flexible with rigid, circular with linear, hierarchy with network. But it is not a motionless balance, there being no such thing in life, and at the moment of the novel, it is wobbling perilously (Le Guin, 1989, 12).

On the other hand, Orgoteyn has chosen quite a different path to follow so that they developed a central government with armed forces and prisons. The rulers of Orgoteyn utilize every means to maintain their power and authority; a police organization that has secret agents everywhere and whose power sometimes exceeds beyond that of the elected, a strict legislation and punishment system including concentration camps and prisons, torture and dishonouring people and an economic system that urges everyone to produce and participate in the progressive delirium. While both societies have no words for war in their languages, they have words for assault, treachery, plotting, conspiracy, exile and imprisonment. They attack each other, even kill people and set the villages on fire but they do not do it in an organized and prearranged manner. "They don't know how to war; they are just like animals or women" (Le Guin, 1976, 51). While Orgoteyn empowers itself with the new arms and weapons for a possible invasion or attack, Karhide, in the leadership of Tibe, cousin of the Karhide King, struggles to imitate the success of Orgoteyn in establishing a central strong government and that's why he tries to evoke a nationalistic pride and awakening, which seems quite odd and alien to Karhide people. He creates a sense of golden history and national victories and stimulates an ancestral past that is full of myths and legends of heroic men. Contrary to shifgretor, Tibe addresses to the weaknesses and losses of people, which paves the way for a militarist and nationalist society. Le Guin, situating these two distinct but alike societies at the two different poles, indicates the consequences of a patriarchal and matriarchal society project and concludes that whether your society is based on feminine or masculine traits, in the final analysis, the evolution of human societies tend to develop autocratic and authoritative oppressors.

The Left Hand of Darkness is an ambiguous utopia where people can exist free from existential anxieties attached to our existence from birth depending on gendered constructions of personality. It is not a criticism of gender, as Le Guin herself stated, it is an experiment to see what would happen if there is no word for war in a society:

The subject of my experiment, then, was something like this: Because our lifelong social conditioning, it is hard for us to see clearly what, besides purely physiological form and 
function, truly differentiates men and women. Are there real differences in temperament, capacity, talent, psychic processes, etc.?_ff so what are they?... One can send an imaginary, but conventional, indeed rather stuffy, young man from Earth into an imaginary culture which is totally free of sex roles because there is no, absolutely no, physiological sex distinction. I eliminated gender, to find out what was left. Whatever was left would be, presumably, simply human. ..... at the very inception of the whole book, I was interested in writing a novel about people in a society that had never has a war. That came first. The androgyny came second (Cause and effect? Effect and cause?) (Le Guin, 1989, 9-11).

The primary outcome of Le Guin's experiment appears to be perplexing. As Le Guin points out a fact many feminists have chosen not to see that feminism is a monolithic body and inescapably leads to metanarratives and the trap of essentialism. Like Foucault, Le Guin sought the main drive that fabricated the patriarchal system without fooling around psychologically and universally taken for granted truths, which, in the final analysis, are debatable. So the gist of human existence you have after peeling off the gender shield is power that is omnipresent and omnipotent and that is diffusive and dispersive. This point of view enables us to see that the underlying raison d'etre of "the sexually constructed social structure" has been and will be the power struggle.

Sigmund Freud once stated that "a happy person never fantasizes, only an unsatisfied one. The motive forces of fantasies are unsatisfied wishes and every single fantasy is the fulfilment of a wish, a connection of unsatisfying reality" (Freud, 1995, 439). Therefore, science fiction and fantasy texts by women primarily reflect either a positive articulation of our desires to a potential world alternating the external reality or distorted envisions of the external reality in an imaginary land duplicating our experiences and frustrations. The Left Hand of Darkness definitely falls into the latter category as it is a dystopic narration of the evolution and inescapability of power and authority where the most generative cause of power and authority and thus exploitation, gender, is eliminated. Le Guin bluntly depicts that gender, indeed, is not the main cause of inequality and suppression but power that is diffusive and evasive, and that is an indispensable part of human existence. Le Guin successfully portrays that the alienation and estrangement from feminine bodies shouldn't be enough to release themselves from their imprisonment in their bodies and gendered positioning, but women have to tackle and reconcile with power and authority that generates at the heart of social and personal relations. 


\section{Works Cited:}

Armitt, Lucie. Contemporary Women's Fiction and the Fantastic. Great Britain: MacMillan Press, 2000

Atteberry, Brian. "Fantasy as Mode, Genre, Formula”. Fantastic Literature: A Critical Reader. Ed. David Sandner. Connecticut: Praeder, 2004. p. 293-309

Barrett, Michelle. Marx'tan Foucault'ya İdeoloji. Çev. Ahmet Fethi. İstanbul: Mavi Ada, 2000

Butler, Judith. Gender Trouble. New York: Routledge, 1990

Butler, Judith. "Performative Acts and Gender Constitution: An Essay in Phenomenology and Feminist Theory". Theatre Journal. The Johns Hopkins University Press. Vol. 40, No. 4 (Dec., 1988), pp. 519-531. http://www.jstor.org/stable/3207893. 06/08/2009

Cixous, Helene. "The Laugh of the Medusa”. Signs. Vol. 1, No. 4. (Summer, 1976), pp. 875893.

Foucault, Michel. History of Sexuality-Vol. 1. New York: Pantheon. 1978.

Freud, Sigmund. "Creative Writers and Day-Dreaming," Ed. Peter Gay. The Freud Reader. London: Vintage: 1995. p. 436-443

Grosz, Elizabeth Volatile Bodies. Indianapolis: Indiana University Press, 1994

Le Guin, Ursula. "Is Gender Necessary?". Dancing At the Edge of The World. New York: Grove Press. 1989. pp. 7-17

Le Guin, Ursula. The Left Hand of Darkness. Ace Books. 1976.

Miéville, China. "Marxism and Fantasy". Fantastic Literature: A Critical Reader. Ed. David

Sandner. Connecticut: Praeder, 2004. p. 334-344.

Oskay, Ünsal. Çağdaş Fantazya. Ankara: Ayko Yayıncılık. 1982.

Robbins, Ruth. "Introduction: Will The Real Feminist Theory Please Stand up”. Literary Theories: A Reader and A Guide. Ed. Julian Wolfreys. Edinburgh: Edinburgh University Press. 1999. pp. $49-59$

Showalter, Elaine. “Towards a Feminist Poetics”. Feminisms: A Reader. Ed. Maggie Humm. Routledge. 1992. p. 381-385.

Suvin, Darko. Metamorphoses of Science Fiction: On the Poetics and History of a Literary Genre. New Haven: Yale University Press. 1979

Walker, Nancy A. Feminist Alternatives. Mississippi: UP of Mississippi, 1990

Waugh, Patricia. Feminine Fictions. London and New York: Routledge.1988 
THE KING İS PREGNANT: THE LEFT HAND OF DARKNESS AND GENDER AS A POWER ISSUE Dr. Öğr. Üyesi Murat GÖÇ 